\title{
Larvae of the blue crab Callinectes sapidus Rathbun, 1896 (Decapoda: Brachyura: Portunidae) in the Balearic Archipelago (NW Mediterranean Sea)
}

\author{
Lydia Png-Gonzalez ${ }^{1 *} \mathbb{D}$, Vanesa Papiol$^{2}$, Rosa Balbín ${ }^{1}$, Joan Enric Cartes ${ }^{3}$ and Aina Carbonell ${ }^{1}$
}

\begin{abstract}
The invasive blue crab Callinectes sapidus has been frequently recorded during the last years along the NW Mediterranean Sea, leading to established populations. Two megalopae of C. sapidus were found during two different oceanographic surveys in open waters of the Balearic Archipelago, in July 2005 and October 2011, previous to the first reference of adult specimens documented in the Balearic sub-basin. The analyzed environmental conditions of the sampling periods allowed us to hypothesize the likely introduction pathways, namely by maritime transport and surface currents. Furthermore, the recorded megalopae seem to enlarge the life history of C. sapidus in regard to its native area, where spawning peaks occur in late July and early August.
\end{abstract}

Keywords: Megalopa, Decapod larvae, Non-indigenous species, Ballast water, Natural dispersion

\section{Introduction}

The blue crab Callinectes sapidus Rathbun, 1896 is native to the West Atlantic, from Canada to Argentina (Squires 1990), and typically found in brackish waters. It is considered one of the most invasive species in the Mediterranean Sea (Streftaris and Zenetos 2006), where it was cited for the first time in 1947 in Hellenic waters (Serbetis 1959), although fishermen observations date back to 1935 in the Gulf of Thessaloniki (Nehring 2011). In the Mediterranean coast of the Iberian Peninsula, adults of C. sapidus have been sporadically recorded since 2004 (Giménez Casalduero et al. 2016). Increasing abundances and established populations have been documented along the subregion in the last decade (Karachle et al. 2016; Fuentes et al. 2019; Box et al. 2020; Mancinelli et al. 2021). However, the species was not

\footnotetext{
*Correspondence: lydiapng@gmail.com

${ }^{1}$ Centro Oceanográfico de Baleares (IEO, CSIC), Muelle de Poniente s/n, 07015 Palma de Mallorca, Spain

Full list of author information is available at the end of the article
}

found in the Balearic Archipelago until 2017 (Garcia et al. 2018).

Here, we report the collection of larvae of C. sapidus prior to the first citation of the species in the Balearic sub-basin. Moreover, the analyzed environmental conditions and the identified larval stages give the opportunity to explore potential introduction pathways and the life history in new invaded areas.

\section{Materials and methods}

Specimens of Callinectes sapidus larvae were obtained during two oceanographic surveys carried out in the Balearic sub-basin (Fig. 1). The first survey was carried out within the framework of the projects BALEARES (CTM 2009-07944 MAR) and TUNIBAL (REN 2003-01176), in July 2005, by sampling a grid of stations around the Balearic Archipelago, between $38^{\circ} \mathrm{N} 0.5^{\circ} \mathrm{E}$ and $42^{\circ} \mathrm{N} 6^{\circ} \mathrm{E}$. Zooplankton samples were collected using doubleoblique tows with a $335 \mu \mathrm{m}$ mesh Bongo net (Carbonell et al. 2014). The second survey was performed within the project ANTROMARE (CTM2009-12214-C02-01/

(c) The Author(s). 2021 Open Access This article is licensed under a Creative Commons Attribution 4.0 International License, which permits use, sharing, adaptation, distribution and reproduction in any medium or format, as long as you give appropriate credit to the original author(s) and the source, provide a link to the Creative Commons licence, and indicate if changes were made. The images or other third party material in this article are included in the article's Creative Commons licence, unless indicated otherwise in a credit line to the material. If material is not included in the article's Creative Commons licence and your intended use is not permitted by statutory regulation or exceeds the permitted use, you will need to obtain permission directly from the copyright holder. To view a copy of this licence, visit http://creativecommons.org/licenses/by/4.0/.
} 


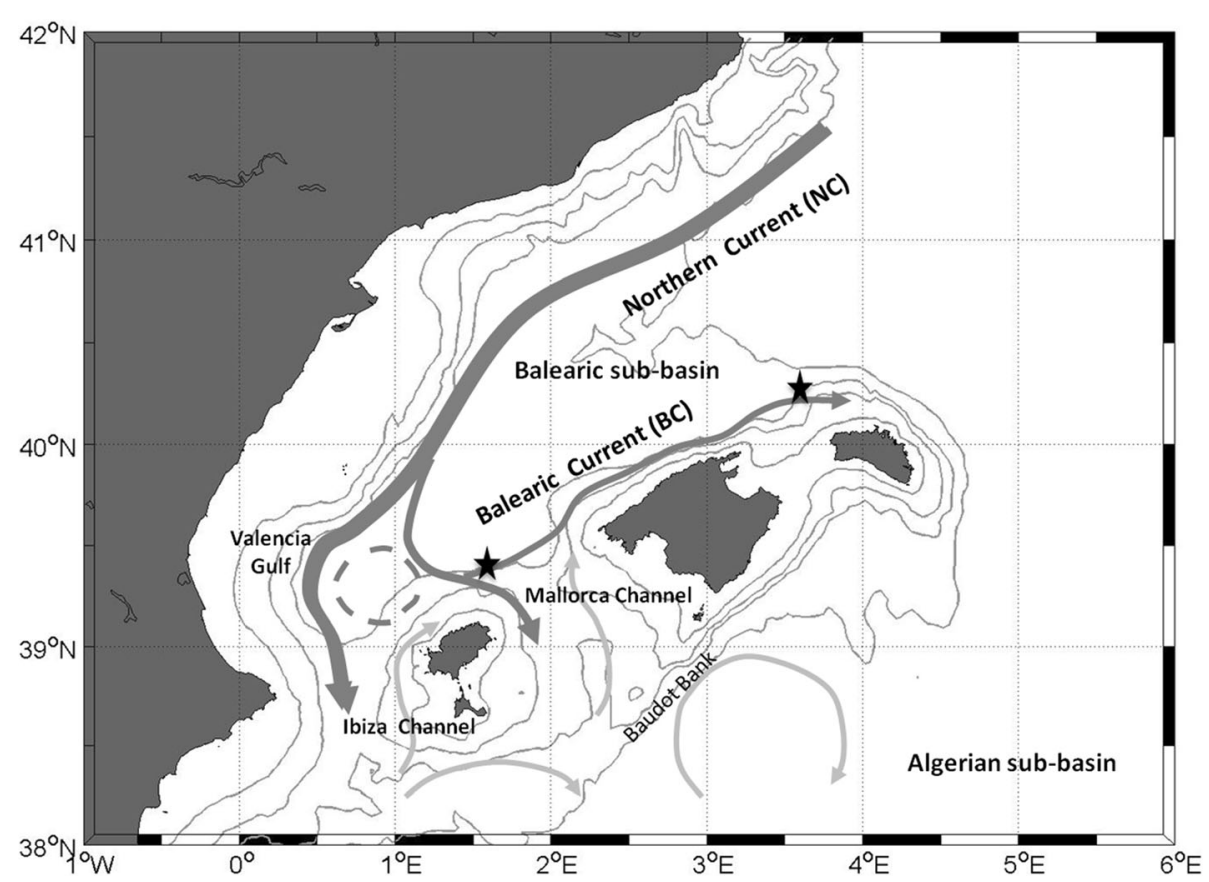

Fig. 1 Map of the Balearic sub-basin with the stations were C. sapidus larvae were collected (stars)

MAR), in October 2011, by sampling 28 stations throughout the Balearic sub-basin, from the Catalonian coast to the Balearic Archipelago. Four zooplankton samples were taken at midwater through oblique hauls with a $500 \mu \mathrm{m}$ mesh WP2 net (Carbonell et al. 2021).

Environmental conditions of the sampling periods were assessed through Sea Surface Temperature (SST; Copernicus: SST_MED_SST_L4_REP_OBSERVATIONS_010_021), from temperature satellite data, and surface currents derived from the Sea Surface Height (SSH; Copernicus: SEALEVEL_ MED_PHY_L4_REP_OBSERVATIONS_008_051), from altimetry satellite data.

All specimens were identified according to Costlow and Bookhout (1959), along with identification keys of Brachyura of the Northeast Atlantic Ocean (Ingle 1992). The larvae were stored at the Centro Oceanográfico de Baleares (COB, IEO-CSIC, Palma de Mallorca) and at the Institut de Ciències del Mar (ICM-CSIC, Barcelona), respectively.

\section{Results and Discussion}

Two larvae of Callinectes sapidus were collected during two different oceanographic surveys in open waters of the Balearic Archipelago (Fig. 1; Table 1).
The first specimen, captured in July 2005, was initially published as Portunus spp. (Carbonell et al. 2014). However, due to the increasing number of $C$. sapidus adult records in the NW Mediterranean Sea, a through full revision of the decapod larvae stored at the COB (IEOCSIC) was performed. One megalopa was re-identified as $C$. sapidus following the description by Costlow and Bookhout (1959), in which the dorsal carapace and the ventral posterior sternum aspects, with a pair of prominent cornua on the posterior margin of the 5th sterna segment, distinguish the species from other Portunus spp. Morphological features of the first megalopa were registered, including a carapace length of $3 \mathrm{~mm}$ and developed pleopods (Fig. 2). The second larva, captured in October 2011, was also identified as a megalopa, although neither biological nor biometric information was obtained (Carbonell et al. 2021). Both specimens were clearly identified by their pointed rostrum with the horizontal placement of the rostral spine, the abdominal pleopods, the appearance of chelae and the cornua project from the posterior edge of cephalothorax (Costlow and Bookhout 1959).

SST and SSH with derived surface currents observed in the sampling days are shown in Fig. 3. The

Table 1 Larvae of C. sapidus located within the frame of two oceanographic surveys

\begin{tabular}{llllcr}
\hline Date & Station & Latitude & Longitude & Tow depth $(\mathbf{m})$ & Bottom depth $(\mathrm{m})$ \\
\hline $10 / 07 / 2005$ & 624 & $40^{\circ} 33.46^{\prime} \mathrm{N}$ & $3^{\circ} 60.10^{\prime} \mathrm{E}$ & $70-0$ & 1600 \\
$18 / 10 / 2011$ & A3W11 & $39^{\circ} 29.20^{\prime} \mathrm{N}$ & $10^{\circ} 34.18^{\prime} \mathrm{E}$ & $910-0$ & 995 \\
\hline
\end{tabular}




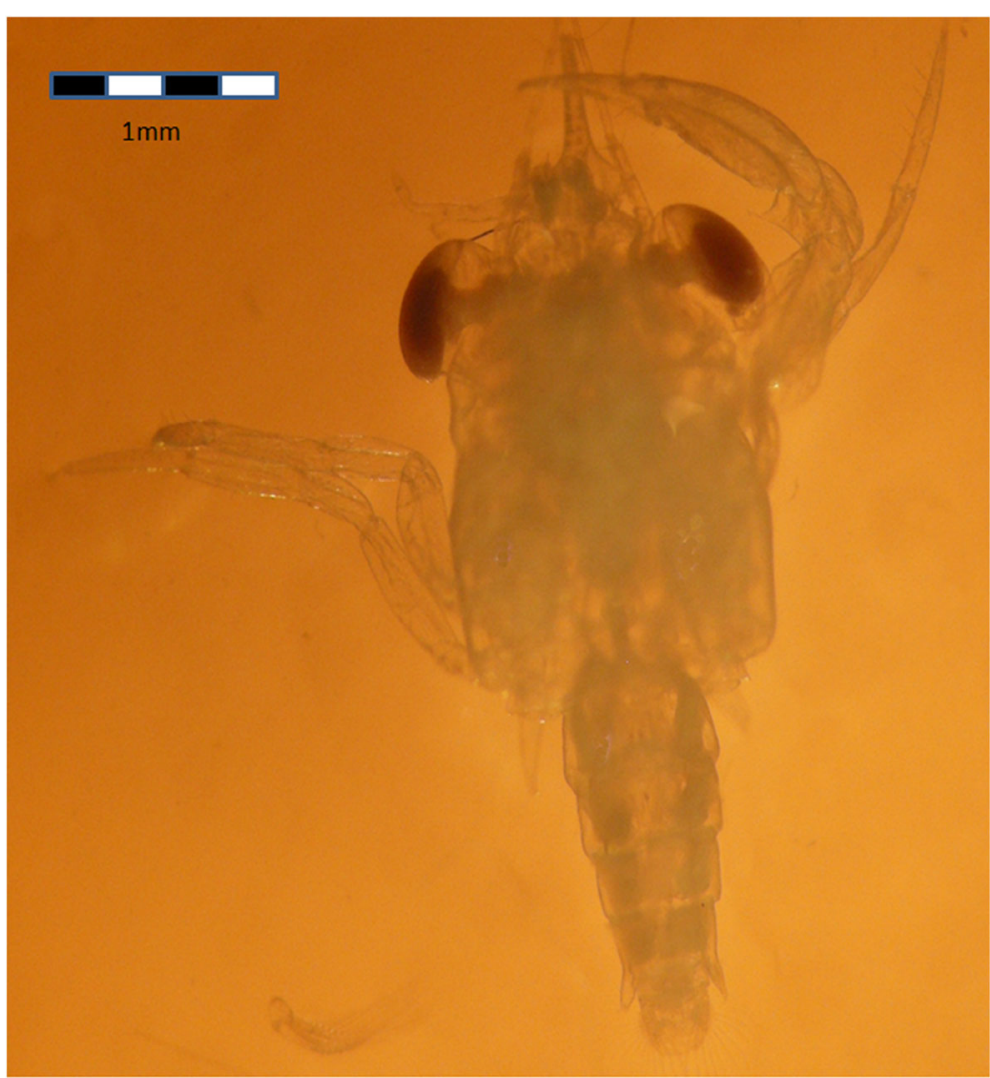

Fig. 2 Megalopa of C. sapidus captured in the Balearic sub-basin in July 2005

temperature in the study area was between 23 and $24{ }^{\circ} \mathrm{C}$ in both periods (Fig. 3A and B). In July 2005, the most intense hydrographic feature was the circulation of recent Atlantic Water that progressed northwards through the Ibiza Channel and recirculated around Ibiza through the Mallorca channel; whilst at the north of the archipelago, the dynamics, not so clearly defined, corresponded to the cyclonic circulation characteristic of the Balearic Sea (Fig. 3C; Balbín et al. 2013). The low hydrographic dynamics found in the Menorca slope suggest that the first megalopa could have been transported to the area by alternative vectors. Zoeal development in open waters requires between 3 and 4 weeks before metamorphosis to the megalopal stage (Epifanio 2019), thus even though natural dispersion could be plausible, it seems less likely due to the long distance that the dispersion entails in the NC stream. In this case, humanmediated vectors such as maritime transport seem a reasonable explanation.

On the other hand, the cyclonic circulation at the Balearic Sea was observed to be more intense in October 2011, when the BC was strengthened by the NC due to the presence of a strong anticyclonic gyre in the south part of the Mallorca channel that avoided neither the normal circulation southwards of the NC nor the clear northward progress of recent Atlantic Waters (Fig. 3D; Balbín et al. 2013). Therefore, the observed hydrographic conditions allow us to hypothesize that the second megalopa found in the Mallorca slope could have been transported in the stream of the NC.

The NC receives significant advective fluxes on its path along the Iberian Peninsula that might reach the Balearic Islands, likely providing a larval pool from existing populations in the mainland. The presence of coastal lagoons in the northern part of the archipelago and a shallow shelf appear to be optimal factors for the settlement of megalopae (Garcia et al. 2018). Adult specimens of $C$. sapidus have been sporadically observed in the Balearic sub-basin since 2004 (P. Abelló, pers. comm.), although the species was not documented until 2012 (Castejón and Guerao 2013; Mancinelli et al. 2017); therefore solitary individuals could have been previously undetected.

Ballast water has been considered so far the most likely introduction vector of $C$. sapidus propagules from its native range (Nehring 2011). In fact, the found megalopae match within some maritime routes of ferries operating between the mainland and the Balearic Archipelago. The first larva, collected in the open slope of Menorca, might fit with the ferry route between 

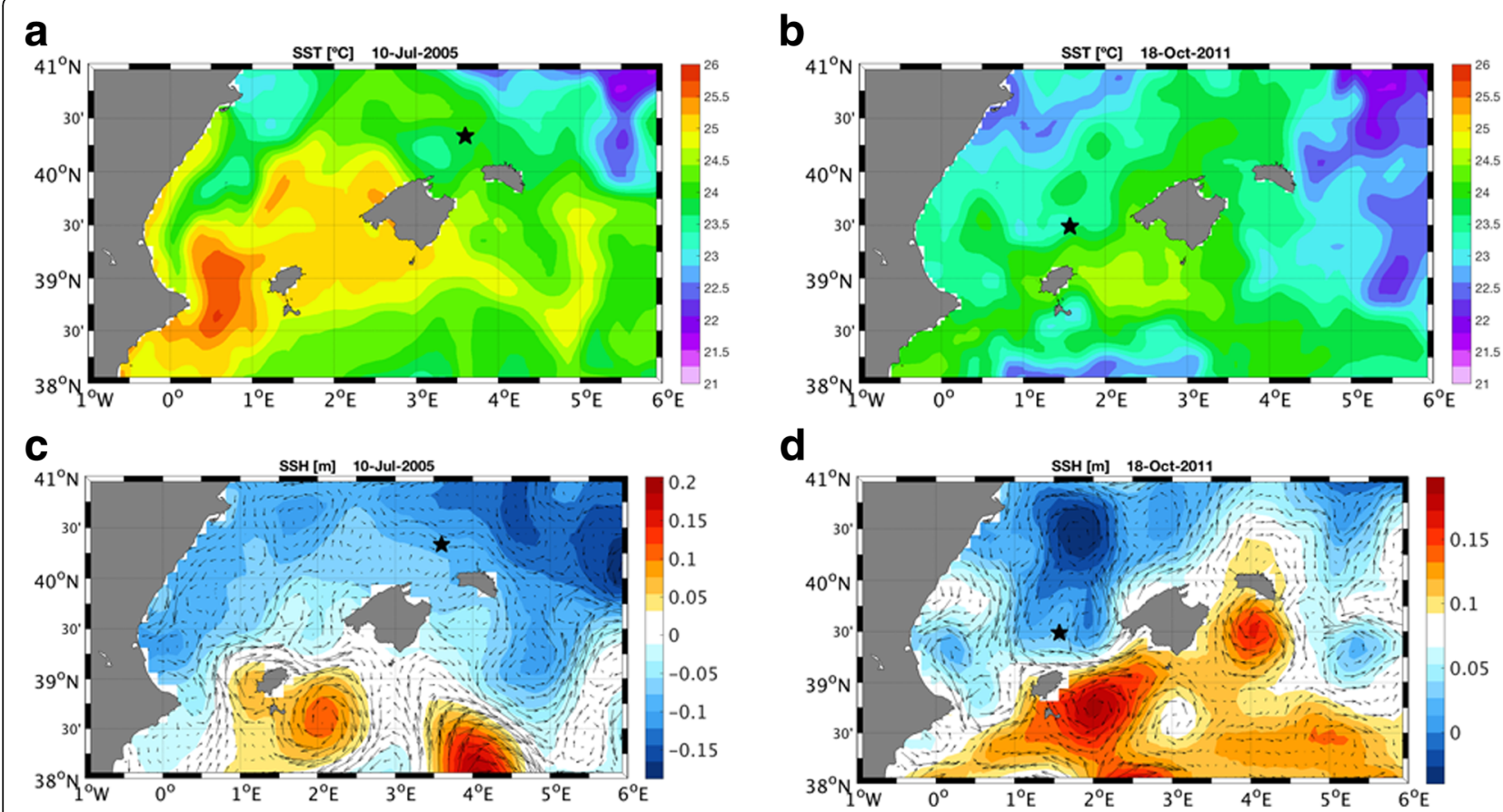

Fig. 3 Sea Surface Temperature (SST) observed in (A) July 2005 and (B) October 2011. Horizontal distribution of surface currents derived from Sea Surface Height (SSH) are shown for (C) July 2005 and (D) October 2011. The position where C. sapidus specimens were collected is indicated (stars)

Ciutadella (Menorca Island) and Barcelona (Catalan Community), but slightly drifted away by the BC. The second larva, located in the open slope of Mallorca, seems to go well with the ferry route between Valencia (Valencian Community) and Palma (Mallorca Island) across the Mallorca Channel. The evidence of the larvae long before the record of adult populations in the archipelago (Garcia et al. 2018) seems to corroborate alternative vectors.

The dispersion model observed in the Atlantic coast of North America demonstrated that C. sapidus larvae are not only retained in the parent estuary, but on the contrary they are able to spread from short to medium distance off the coast (Epifanio 1995; Johnson and Perry 1999). Our findings may support the dispersion model through the open ocean that make the islands vulnerable to secondary introduction of non-indigenous species through their early life stages (Evans et al. 2015).

In the present study, the megalopae were recorded in early July and mid-October, which seems to enlarge the larval history of $C$. sapidus in regard to its native area. Yet, invasive populations might show differing life history dynamics than the native ones, and in the Eastern Mediterranean spawning has been reported from much earlier (i.e. from mid spring) and lasting longer (up to eight months) than in the $C$. sapidus native range
(Sumer et al. 2013; Kevrekidis and Antonadiou 2018; Türeli et al. 2018), where reproduction occurs throughout the summer with a spawning peak in late July and early August (Epifanio 1995). Given the monthlong duration of larval development (Epifanio 2019), the earlier and longer reproductive period of $C$. sapidus in the Mediterranean squares well with the findings of megalopae in both July and October, and could be an additional factor favoring the dispersal of the species in the Mediterranean Sea.

\section{Conclusions}

The two megalopae of Callinectes sapidus found in the Balearic Archipelago, in two different periods between summer and autumn, and long before than adult specimens were recorded in the islands, could have different introduction pathways. The first larva found in the Menorca slope could be a primary introduction by maritime transport, although natural dispersion cannot completely be discarded. The major presence of coastal lagoons and the shallow shelf could favor the megalopal settlement and later establishment of populations in this area. Measures such as avoiding ballast water emptying in the proximity of the islands could be an effective way to reduce and control blue crab populations. For the larva found in the Mallorca slope, secondary introduction through 
natural dispersion seems more feasible. The topographical complex of Balearic channels makes the archipelago vulnerable to secondary introduction of non-indigenous species, thus increasing the distributional range in the introduced area. This natural pathway may well difficult effective measures of species elimination and control in the area.

\section{Abbreviations}

BC: Balearic Current; NC: Northern Current; SSH: Sea Surface Height; SST: Sea Surface Temperature

\section{Acknowledgements}

This study was carried out within the framework of different projects financed by the Spanish Government. The authors wish to thank all the participants in the cruises where larvae were sampled.

\section{Authors' contributions}

AC and LPG conceived the publication, and wrote the manuscript. JEC and VP supplied the second specimen. AC identified both larvae. RB provided the oceanographic landscape and contributed to analyze the hydrographic dynamics. All authors participated in discussion of the results and critically reviewed the manuscript. The author(s) read and approved the final manuscript.

\section{Funding}

The oceanographic surveys were carried out within the frame of the projects BALEARES (CTM2009-07944/MAR), TUNIBAL (REN 2003-01176) and ANTROMARE (CTM2009-12214-C02-01/MAR). This research has been performed in the scope of the LIFE-IP INTEMARES project (LIFE15 IPE/ES/000012), financed by the European Commision and coordinated by Fundación Biodiversidad, as part of the Ministry for the Ecological Transition and the Demographic Challenge.

\section{Availability of data and materials}

The datasets used and/or analyzed during the current study are available from the corresponding author.

\section{Declarations}

Ethics approval and consent to participate

Not applicable.

\section{Consent for publication}

Not applicable.

\section{Competing interests}

The authors declare that they have no competing interests.

\section{Author details}

${ }^{1}$ Centro Oceanográfico de Baleares (IEO, CSIC), Muelle de Poniente s/n, 07015 Palma de Mallorca, Spain. ${ }^{2}$ Escuela Nacional de Estudios Superiores, Unidad Mérida, Universidad Nacional Autónoma de México, Carretera Mérida-Tetiz, Km 4, Yucatán 97357 Ucú, México. ${ }^{3}$ Institut de Ciències del Mar (ICM-CSIC), Passeig Marítim de la Barceloneta, 27-49, 08003 Barcelona, Spain.

Received: 21 December 2020 Accepted: 14 October 2021

Published online: 03 November 2021

\section{References}

Balbín R, López-Jurado JL, Flexas MM, Reglero P, Vélez-Velchí P, González-Pola C, Rodríguez JM, García A, Alemany F. Interannual variability of the summer circulation around the Balearic Islands. J Mar Syst. 2013;138:70-81.

Box A, Colomar V, Sureda A, Tejada S, Nuñez-Reyes V, Cohen-Sanchez A, Avila T, Forteza V, Castello M, Valverde N, Pinya S. Next step of the colonization of the Balearic Islands (Spain) by invasive Atlantic blue crab, Callinectes sapidus Rathbun, 1896 (Crustacea: Decapoda: Portunidae). Bioinvasions Rec. 2020;9: $259-65$.
Carbonell A, Aparicio-González A, Papiol V, Cartes JE. Composition and distribution of the larval decapod community in the deep sea of the Western Mediterranean Sea Balearic Sub-basin. Fish Oceanogr. 2021;30:205-18.

Carbonell A, Tor A, Álvarez-Berastegui D, Vélez-Belchi P, dos Santos A, Balbín R, Alemany F. Environmental driving forces determining the epipelagic decapod larval community distribution in the Balearic Sea (Western Mediterranean). Crustaceana 2014:87: 686-714.

Castejón D, Guerao G. A new record of the American blue crab, Callinectes sapidus Rathbun, 1896 (Decapoda: Brachyura: Portunidae), from the Mediterranean coast of the Iberian Peninsula. Bioinvasions Rec. 2013;2:141-3.

Costlow JD, Bookhout CG. The larval development of Callinectes sapidus Rathbun reared in the laboratory. Biol Bull. 1959;116:373-96.

Epifanio CE. Transport of Blue Crab (Callinectes sapidus) larvae in the waters off Mid-Atlantic States. Bull Mar Sci. 1995;57:713-25.

Epifanio CE. Early life history of the blue crab Callinectes sapidus: A review. J Shellfish Res. 2019;38:1-22.

Evans J, Barbara J, Schembri P. Updated review of marine alien species and other 'newcomers' recorded from the Maltese Islands (Central Mediterranean). Mediterr Mar Sci. 2015;16:225-44.

Fuentes MA, Torrent L, Barrera S, Boix D. Rapid invasion of the American blue crab Callinectes sapidus Rathbun, 1896 in the North-East of the Iberian Peninsula. Bioinvasions Rec. 2019:8:113-8.

Garcia L, Pinya S, Colomar V, París T, Puig M, Rebassa M, Mayol J. The first recorded occurrences of the invasive crab Callinectes sapidus Rathbun, 1896 (Crustacea: Decapoda: Portunidae) in coastal lagoons of the Balearic Islands Spain). Mar Biodivers Rec. 2018:7:191-6.

Giménez Casalduero F, Ramos Esplá AA, Izquierdo Muñoz A, Gomaríz Castillo F, Martínez Hernández FJ, González-Carrión F. Alloctonous Marine Invertebrates in the Mar Menor Lagoon. In: Leon VM, Bellido JM, editors. Mar Menor: una laguna singular y sensible. Evaluación científica de su estado. Madrid: Instituto Español de Oceanografía, Ministerio de Economía y Competitividad; 2016. pp. 157-78.

Ingle R. Larval Stages of Northeastern Atlantic Crabs: An illustrated key. London: Chapman \& Hall; 1992.

Johnson DR, Perry HM. Blue crab larval dispersion and retention in the Mississippi Bight. Bull Mar Sci. 1999;65:129-49.

Karachle PK, Angelidis A, Apostolopoulos G, Ayas D, Ballesteros M, Bonnici C et al. New Mediterranean Biodiversity Records (March 2016). Mediterr Mar Sci. 2016;17:230-52.

Kevrekidis K, Antoniadou C. Abundance and population structure of the blue crab Callinectes sapidus (Decapoda, Portunidae) in Thermaikos Gulf (Methoni Bay), Northern Aegean Sea. Crustaceana. 2018;91:641-57.

Mancinelli G, Chainho P, Cilenti L, Falco S, Kapiris K, Katselis G, Ribeiro F. The Atlantic blue crab Callinectes sapidus in southern European waters: Distribution, impact and prospective invasion management strategies. Mar Poll Bull. 2017:119:5-11.

Mancinelli G, Bardelli R, Zenetos A. A global occurrence database of the Atlantic blue crab Callinectes sapidus. Sci Data. 2021:8:111.

Nehring S. Invasion History and Success of the American Blue Crab Callinectes sapidus in European and Adjacent Waters. In: Galil BS, Clark PF, Carlton JT, editors. the Wrong Place - Alien Marine Crustaceans: Distribution, Biology and Impacts. Netherlands: Springer; 2011. pp. 607-24.

Serbetis C. Un nouveau crustacé comestible en mer Egée Callinectes sapidus Rath. (Decapod. Brach.). General Fisheries Council for the Mediterranean, Proceedings and technical papers 1959:5:505-507.

Squires HJ. Decapoda Crustacea of the Atlantic Coast of Canada. Can Bull Fish Aquat Sci. 1990;221:1-532

Streftaris N, Zenetos A. Alien Marine Species in the Mediterranean - the 100 'Worst Invasives' and their Impact. Med Mar Sci. 2006:7:87-118.

Sumer C, Teksam I, Karatas H, Beyhan T, Aydin CM. Growth and Reproduction Biology of the Blue Crab, Callinectes sapidus Rathbun, 1896, in the Beymelek Lagoon (Southwestern Coast of Turkey). Turkish J Fish Aquat Sci. 2013;13: 675-84.

Türeli C, Yeşilyurt IN, Nevşat IE. Female reproductive pattern of Callinectes sapidus Rathbun, 1896 (Brachyura: Portunidae) in Iskenderun Bay, Eastern Mediterranean. Zool Middle East. 2018:64:55-63.

\section{Publisher's Note}

Springer Nature remains neutral with regard to jurisdictional claims in published maps and institutional affiliations. 